\title{
DETERIORATIONS IN BIOLOGICAL AND BIOCHEMICAL ASPECTS OF BIOMPHALARIA ALEXANDRINA SNAILS EXPOSED TO METHANOL EXTRACT OF CALLISTEMON CITRINUS LEAVES
}

By

AZZA H. MOHAMED ${ }^{1}$, GAMALAT Y.OSMAN ${ }^{1}$, MOHAMED A. EL-EMAM ${ }^{2}$, HODA ABDEL-HAMID ${ }^{2}$ AND RASHA E.M. ALI ${ }^{2^{\star}}$

Department of Zoology, Faculty of Science, Menoufia University ${ }^{1}$, Shebin El-Kom, and Department of Medical Malacology, Theodor Bilharz Research Institute ${ }^{2}$,

Embaba P. O. Box 30, Giza, Egypt ( ${ }^{*}$ Correspondence: roshaezzat@yahoo.com)

\section{Abstract}

Schistosomiasis is one of the deleterious parasitic diseases in many developing countries. One important approach to control the disease is to eliminate its intermediate hosts. Therefore, methanol extract from Callistemon citrinus leaves was evaluated against biological \& biochemical aspects of Schistosoma mansoni infected and uninfected B. alexandrina snails, in addition to examination the histological changes in tissues of the snails' digestive gland. The plant extract exhibited considerable molluscicidal potency against $B$. alexandrina snails. The egg-laying capacity and reproductive rate $\left(\mathrm{R}_{0}\right)$ of $S$. mansoni infected and uninfected snails were suppressed post exposure to $\mathrm{LC}_{25}$ of methanol extract for $24 \mathrm{~h} /$ week for 4 successive weeks. Reduction rate of $\mathrm{R}_{0}$ for snails infected only and those infected treated with $\mathrm{LC}_{25}$ were $65.8 \%$ and $70.9 \%$, respectively. Infection rates of B. alexandrina snails with $S$. mansoni and cercarial production/infected snail were reduced as a reflection of their exposure to $\mathrm{LC}_{10}$ of the plant extract either pre-, during or post their exposure to miracidia. The total number of hemocytes of $S$. mansoni infected and uninfected snails was elevated post $24 \mathrm{~h}$ of exposure to the plant extract. However, it was reduced after 4 weeks of successive exposure to the extract, but the large granulocytes were elevated. Also, exposure of B. alexandrina snails (infected and uninfected) to the plant extract caused deleterious morphological changes in their hemocytes. The activities of antioxidant enzymes LPO, CAT \& SOD were elevated in tissue homogenate of uninfected snails after one week of exposure to the extract, while that of GSH was decreased. Moreover, the plant extract deteriorated the histological characters of digestive gland cells in treated snails ranged from degeneration and necrotic of its tubules, atrophy of different cell types and hyaline substance in enlarged digestive lumen..

Key words: Biomphalaria alexandrina snails, Callistemon citrinus, Schistosoma mansoni, hemocytes, antioxidant enzymes, histology.

\section{Introduction}

Schistosomiasis, an acute and chronic parasitic disease, is a major health problem in tropical and subtropical countries (WHO, 2016). One of the methods for controlling schistosomiasis is to delink the life cycle of the parasite by combating its snail host(s). Control is a key intervention to achieve the World Health Assembly's goal for schistosomiasis elimination (King and Bertsch, 2015). There is an increase demand to develop new molluscicides of medicinal plant origin, as alternative to chemical ones, which proved to have several advantages over the synthetic compounds (Belet, 2015). The body cavity of fresh water snails (Gast- ropod) is filled with hemolymph which contains dissolved hemoproteins and several kinds of hemocytes which are the principal line of cellular defense involved in destruction of $S$. mansoni larvae inside the snail intermediate host (Larson et al, 2014). The response patterns, density and functions of hemocytes, can be affected by pathogens, xenobiotics and parasites (Livingstone et al, 2000).

Immune functions are complemented by an array of killing mechanisms release of degradative and oxidative enzymes (Renwrantz et al, 1996) and high reactive oxygen metabolites generation (Arumugam et al, 2000). Antioxidant enzymes activity proved 
important to clarify immune response of organisms exposed to different stresses (Dhawan, 2005).

Plants contain a variety of antioxidant and free radical scavenging activities (Sampath et al, 2016). Callistemon citrinus known as Bottle brush of family Myrtaceae has a great medicinal importance; molluscicidal potency (Gawish et al, 2008), antioxidant and hepatoprotective activities (El-Dib and El-Shenawy, 2008) and antibacterial and antifungal properties (Dongmo et al, 2010).

This study aimed to evaluate the impact of methanol extract of Callistemon citrinus leaves on biological, histological and immunological parameters of Biomphalaria alexandrina.

\section{Materials and Methods}

Biomphalaria alexandrina snails $(7-9 \mathrm{~mm})$ were collected from irrigation system in Giza Governorate. They were examined for natural trematode infections, then negative and healthy specimens were maintained at Department of Medical Malacology, Theodor Bilharz Research Institute (TBRI), before usage; snails were kept for 4 weeks (10snails/L dechlorinated water, $25 \pm 1{ }^{\circ} \mathrm{C}$ ).

Miracidia: S. mansoni ova were obtained from Schistosomiasis Biological Supply Center (SPSC), TBRI, left in clean dechlorinated water for hatching under a desk lamp, fresh hatched miracidia were used in bioassay and infection tests.

Plant species: Callistemon citrinus (Myrtaceae) was collected from the Giza Zoo, and was kindly identified by Dr. Zaki Turky, Prof of Plant Taxonomy, Department of Botany, Faculty of Science, Menoufia University. The leaves were washed, shade dried, powdered by an electric mill and stored in dry clean dark glass bottle.

Plants' extract: Leaves dry powder was extracted by soaking of $25 \mathrm{~g} / 250 \mathrm{ml} 95 \%$ methanol for 3 days. Solvent was filtered, distilled off under vacuum and residues were stored in clean dry dark bottles (Kamel et al, 2011).
Bioassay: A series of concentrations was prepared from methanol extract of $C$. citrinus leaves on the basis of weight/volume. Three, each of 10snails/L were prepared for each concentration. Another three replicates in dechlorinated water were used as control $\left(25 \pm 1^{\circ} \mathrm{C}\right)$. Exposure and recovery periods were $24 \mathrm{~h}$ for each. Mortality rates $\left(\mathrm{LC}_{50}\right.$ $\& \mathrm{LC}_{90}$ ) were calculated using the Probit Prob ananslysis (ver 20 for Windows).

Effect of methanol extract on mature $B$. alexandrina: The sublethal effects $\left(\mathrm{LC}_{10} \&\right.$ $\mathrm{LC}_{25}$ ) of methanol extract on reproductive rate, histological features of digestive gland, morphology of hemocytes and types and some antioxidant enzymes of normal and $S$. mansoni infected snails was evaluated 4 weeks post exposure. Snails were divided into 4 groups: $\mathbf{G} 1$ was maintained as untreated and uninfected control group, G2 ${ }^{\text {nd }}$ was exposed to $S$. mansoni miracidia representing infected group, G3 was exposed to sublethal concentrations of methanol extract as treated uninfected group, and G4 was exposed to both methanol extract and $S$. $m a-$ nsoni miracidia representing treated-infected group.

Egg-laying capacity: Six groups of adult snails were prepared. Two were untreated with methanol extract and kept as control uninfected and control infected. Others were exposed to $\mathrm{LC}_{10} \& \mathrm{LC}_{25}$ of methanol extract for $24 \mathrm{~h}$ weekly for 4 successive weeks as infected treated and uninfected treated. Three replicates, each of 10 snails as 7-9 $\mathrm{mm} / \mathrm{L}$, were used for each snail group. Concentrations were weekly changed by fresh ones. Snails were daily fed oven dried lettuce leaves. Aquaria of treated and untreated snails were provided with foam sheets for oviposition. Eggs laid on these sheets and on the aquaria walls were weekly counted using a stereomicroscope and hand lens (10x). Dead snails were removed daily and the following parameters were weekly recorded (Mohamed et al, 2012). Lx (survival rate as a proportion of corrected one), Mx (number 
of eggs/snail/week) and $\mathrm{R}_{0}$ (reproductive rate: summation of $\mathrm{Lx} \mathrm{Mx}$ ).

Infection rate effect on $B$. alexandrina: exposed to miracidia as 10miracidia/snail, for $24 \mathrm{~h}$ illumination. They were maintained in clean dechlorinated water $\left(25 \pm 1^{\circ} \mathrm{C}\right)$ for prepatency. Snails were exposed to $\mathrm{LC}_{10} \&$ $\mathrm{LC}_{25}$ of methanol extract at 1day pre-, during and 15 days post-exposure. Three replicates, each of 10snails/L, were prepared for each concentration. Another three replicates were exposed to miracidia and similarly treated as the experimental snails to cercarial emergence.

Effect on histology of $B$. alexandrina: Four groups of snails were used. Two were untreated with $C$. citrinus methanol extract; one was as clean control and $2^{\text {nd }}$ was exposed to $S$. mansoni miracidia (untreated infected). The other two were treated with $\mathrm{LC}_{50}$ of the extract for $24 \mathrm{~h}$, one was as treated only and the second group was exposed to $S$. mansoni (treated infected). Digestive gland of survived snails of each group was dissected out and fixed in a Boun's solution. i.e., digestive gland of snails exposed to the plant extract only were prepared after $24 \mathrm{~h}$ of treatment, but infected treated and infected untreated groups were done after $1 \& 3$ weeks of miracidial exposure, respectively. Thin sections $(5 \mu \mathrm{m})$ were prepared and stained with Delafield's hematoxyline and eosin (Ragheb et al, 2013). Sections were examined and photographed by the Carl Zeiss, Germany microscopy.

Effect on snails' hemolymph and antioxidant enzymes: For total hemocytes number and types, six groups of $B$. alexandrina were used. G1 \& G2 were exposed to $\mathrm{LC}_{10}$ $\& \mathrm{LC}_{25}$ of plant extract only for $24 \mathrm{~h}$ weekly for 4 successive weeks (treated normal). G3 $\& \mathrm{G} 4{ }^{\mathrm{t}}$ were individually exposed to $S$. mansoni miracidia (5miracidia/snail) for $24 \mathrm{~h}$, followed by exposure to $\mathrm{LC}_{10} \& \mathrm{LC}_{25}$ as in G1. G5 was exposed to miracidia only (untreated infected or control infected), and G6 was kept as clean control (untreated normal). Hemolymph samples were collected from survived snails in each group after $24 \mathrm{~h}, 1,2$ \& 4 weeks post-exposure (Nduka and Harrison, 1980). Snails' soft tissues were centrifuged and supernatant was used for antioxidant enzymes determination. Total number of hemocytes, types and morphological alterations were recorded (Abou-El-nour et $a l, 2015)$.

Antioxidant enzymes: Antioxidant enzymes Catalase (CAT, Aebi, 1984), Glutathione reduced (GSH, Beutler et al, 1963), Lipid peroxide (LPO, Ohkawa et al, 1979) and Superoxide dismutase (SOD, Nishikimi et $a l$, 1972) were determined in supernatant previously prepared from tissue homogenate of the experimental and control groups.

Statistical analysis: Data were analyzed for significant differences between mean values of the test and control groups by " $\mathrm{t}$ " test (Spiegel, 1981), and between percenttages by Chi-square (Southwood, 1978), using the SPSS computer program (version 20.0 Windows).

\section{Results}

Toxicity of $C$. citrinus methanol extract to B. alexandrina snails was 5.9 times that of water extract on basis of $\mathrm{LC}_{90}$ after $24 \mathrm{~h}$ of exposure (37.8 \& 223.6ppm, respectively). Methanol extract impact on biological, histological and immunological aspects of $B$. alexandrina was tested (Tab. 1).

Survival rate of snails at $1^{\text {st }}$ shedding: Exposure of B. alexandrina snails to $\mathrm{LC}_{10}(9.3$ ppm) and $\mathrm{LC}_{25}$ (17.2 ppm) from C. citrinus methanol extract for $24 \mathrm{~h}$ either at 1 day pre-, during or at 15 days post-miracidial exposure reduced their survival rate at $1^{\text {st }}$ shedding compared to their corresponding control groups (Tab. 2). Reduction rates of groups exposed to $\mathrm{LC}_{10}$ at 1day pre, during and at 15 days post- exposure were $18.7 \%$, $26.7 \%$ and $64.7 \%$, respectively $(P<0.05 \&$ 0.001). Raising concentration to $\mathrm{LC}_{25}$ caused more reduction for groups at during- \& 15 days post-exposure were $40 \% \& 70.6 \%$, respectively $(P<0.01 \& 0.001)$.

The $24 \mathrm{~h}$ of snails' exposure to $\mathrm{LC}_{10}$ of $C$. citrinus extract at 1 day pre-, during or at 15 
days post-exposure reduced infection with $S$. mansoni. Infection rate during miracidial exposure was $72.73 \%$ compared to $86.67 \%$ for control group $(P<0.05)$. More reduction was at 15 days post-exposure, as infection rate was $33.33 \%$ compared to $82.35 \%$ for control snails $(P<0.001)$. Also, infection rate of snails treated with $\mathrm{LC}_{25}$ at 15 days postexposure $(40 \%)$ was significantly lower than corresponded controls $(82.35 \%, P<0.001)$.

Cercarial shedding (cercariae/snail): Cercarial production/snail from the groups exposed to $\mathrm{LC}_{10}$ and $\mathrm{LC}_{25}$ at the three modes of miracidial exposure was less than corresponding control groups. Highest reduction rate was in snails exposed to $\mathrm{LC}_{25}$ at 15 days post-exposure, recording $63.1 \%$ compared to $18.4 \% \& 45.8 \%$ for groups treated at 1 day pre- and during exposure, respectively.

Snails' survival rate $\left(\mathrm{L}_{\mathrm{X}}\right)$ : Exposure of $S$. mansoni uninfected snails to $\mathrm{LC}_{10} \& \mathrm{LC}_{25}$ of extract for $24 \mathrm{~h}$ weekly for 4 successive weeks reduced survival rate $\left(\mathrm{L}_{\mathrm{X}}\right)$ to be 0.56 $\& 0.50$ at the $4^{\text {th }}$ week, respectively, compared to 0.90 in control group (Tab. 3). Infected snails' $\mathrm{L}_{\mathrm{X}}$ values were sharply reduced; $0.43 \& 0.38$ at $2^{\text {nd }}$ week post exposure to these concentrations, respectively, as compared with 0.6 for infected untreated control group. Few snails survived only at $\mathrm{LC}_{25}$ within three weeks, dead at $4^{\text {th }}$ week $\left(\mathrm{L}_{X}=0.0\right)$ compared to 0.23 for infected untreated control snails. Snails' fecundity $\left(\mathrm{M}_{\mathrm{X}}\right)$ and reproductive rate $\left(\mathrm{R}_{0}\right)$ : $S$. mansoni uninfected snails exposed to $\mathrm{LC}_{10} \& \mathrm{LC}_{25}$ of $C$. citrinus extract laid few number of eggs/ snail/week throughout the experimental period (4 weeks) compared to control group. $\mathrm{M}_{\mathrm{X}}$ values at $2^{\text {nd }}$ week were $2.0 \& 2.4$ eggs/ snail compared to 4.5 eggs/control. At $4^{\text {th }}$ week, treated snails suffered much as few survived at $\mathrm{LC}_{25}$ laid very few eggs $\left(\mathrm{M}_{\mathrm{X}}=0.01 \mathrm{eggs} / \mathrm{snail}\right)$, but at $\mathrm{LC}_{10}$ failed to lay eggs $\left(\mathrm{M}_{\mathrm{X}}=0.0\right)$.

Exposure of $S$. mansoni infected snails to the concentrations decreased $M_{X}$ values compared to infected untreated controls (Tab. 3). At $3^{\text {rd }}$ week, $M_{X}$ values for snails exposed to $\mathrm{LC}_{10} \& \mathrm{LC}_{25}$ were $0.02 \& 0.1$ eggs/snail compared to 1.1eggs/infected untreated controls. By $4^{\text {th }}$ week, snails survived at $\mathrm{LC}_{10}$ failed to lay eggs $\left(\mathrm{M}_{\mathrm{X}}=0.0\right)$ compared to 0.8 eggs/infected untreated controls.

As to reproductive rate $\left(\mathrm{R}_{0}\right)$ of uninfected snails exposed to extract, was reduced as compared with controls. Similar observations were recorded for $S$. mansoni infected snails treated with the concentrations. So, $\mathrm{R}_{0}$ was reduced by $16 \%$ in each concentration in proportion to infected untreated controls.

Histology of treated snails: Exposure of snails to $\mathrm{LC}_{50}$ of methanol extract for $24 \mathrm{~h}$ revealed certain histopathological changes in digestive gland. Normal histological structure of $B$. alexandrina digestive gland includes glandular tubules interspersed within connective tissues. The epithelium is rested on thin basement membrane; at least 3-4 types of cells can be recognized in the snail, digestive, calcium and excretory cells (Fig. 1A). Exposure to $C$. citrinus caused wall thickness of digestive gland cells, losing their shape and hyaline substance appeared in enlarged digestive lumen (Fig. 1B). B. alexandrina exposed to $S$. mansoni miracidia only for $24 \mathrm{~h}$ (infected untreated) different developmental stages of sporocycts in the digestive gland tubules and cercariae after 3 weeks of miracidial exposure were detected (Fig.1C). In case of $B$. alexandrina snails exposed for 24 h to $S$. mansoni miracidia and treated with $\mathrm{LC}_{50}$ of $C$. citrinus (infected treated) atrophied shrunk sporocycts (S), big vacuoles (V) and thickened degenerated cells and connective tissue between the digestive gland tubules were observed (Fig. 1D).

Total hemocytes for S. mansoni uninfected and infected snails: A significant increase in total hemocytes of uninfected snails post 24 h of exposure to $C$. citrinus extract was recorded (Tab. 4). Recorded number at $\mathrm{LC}_{25}$ was 3250 cells $/ \mathrm{ml}$ compared to 2340 cells/ $\mathrm{ml}$ for control group $(P<0.05)$. After one week of exposure, this parameter was significantly decreased to 750 cells $/ \mathrm{ml}$ for snails at 
$\mathrm{LC}_{10}$ compared to 2150 cells $/ \mathrm{ml}$ for controls $(P<0.001)$. After $2 \& 4$ weeks of exposure total number of hemocytes for snails treated with $\mathrm{LC}_{10} \& \mathrm{LC}_{25}$ was not significant from corresponding controls. After 4 weeks exposure, total number of hemocytes of snails at $\mathrm{LC}_{25}$ was 3050 cells $/ \mathrm{ml}$ compared to 2700 cells/ $\mathrm{ml}$ for controls $(P>0.05)$. As to $S$. $m a$ $n$ soni infected $B$. alexandrina total number of hemocytes post $24 \mathrm{~h}$ of exposure to $\mathrm{LC}_{10}$ \& $\mathrm{LC}_{25}$ of extract was significantly increased compared to controls. At $\mathrm{LC}_{25}$ was 3000 cells $/ \mathrm{ml}$ compared to 1600 cells $/ \mathrm{ml}$ for controls $(P<0.001)$. This was significant decreased for snails at $1,2 \& 4$ weeks post exposure compared to corresponding controls. Number of hemocytes after 4 weeks of snails exposure to $\mathrm{LC}_{25}$ was 1950 cells $/ \mathrm{ml}$ compared to 2950 cells $/ \mathrm{ml}$ for controls $(P<0.01)$.

Hemocytes' types and percentages were affected by snails' exposure to extract concentrations. Hyalinocytes values after $24 \mathrm{~h}, 1$ \& 2 weeks of exposure to $\mathrm{LC}_{25}$ were significantly higher than controls, but large granulocytes were significantly lower. Long period to 4 weeks significantly increased granulocytes for snails exposed to $\mathrm{LC}_{10}$ recording $65 \%$ compared to $41 \%$ for controls $(P<0.001)$. Snails treated with $C$. citrinus concentrations post exposure to $S$. mansoni miracidia, types of hemocytes were deteriorated and large granulocytes at $4^{\text {th }}$ week of treatment were significantly higher $(51 \%)$ than controls $(21 \%, P<0.001)$.

The light microscopy photographs of uninfected untreated (control) B. alexandrina hemocytes (Fig. 2A) showed two distinct types of hemocytes, granulocytes and hyalinocytes. Granulocytes showed two types, large and small cells. Large ones were variable in size with small nucleus and dense cytoplasmic contents due to refractile granules. Hyalinocytes were small circular in shape with a clear dense cell membrane and a large nucleus. For S. mansoni unin-fected treated snails (Fig. 2B\&C) hyaline-cytes emit fine long extension (Fp) and a degeneration of large granulocyte cytoplasm with condensed vacuoles $(\mathrm{Cv})$, irregular cell walls and large eccentric nucleus. In S. mansoni infected snails (Fig. 2D) large granulocytes (LG) exhibited deformed cell walls (Dw) and condensed granules (CGR). Moreover, large granulocytes of infected treated snails showed incomplete cell division with large granules and having two nuclei (Fig. 2E).

The activities of the enzymes CAT and SOD increased in tissue homogenate of $S$. mansoni uninfected snails post one week of exposure to $\mathrm{LC}_{10} \& \mathrm{LC}_{25}$ of extract compared to controls (Tab. 5). Enzymes activeties after 2 and 4 weeks of snail exposure to concentrations were less than controls. After 4 weeks of snails exposure to $\mathrm{LC}_{25}$ CAT activity was $9.9 \mathrm{U} / \mathrm{g}$ tissue compared to $27.3 \mathrm{U}$ $\mathrm{Ig}$ tissue of controls (reduction rate $=63.7 \%$, $P<0.001)$.

For lipid peroxide (LPO) concentration in snails' tissue homogenate after one week exposure to $\mathrm{LC}_{25}$ of extract showed few elevation compared to controls $(119.4 \mathrm{~nm} / \mathrm{g}$ tissue compared to $107.2 \mathrm{~nm} / \mathrm{g}$ tissue) After 2 \& 4 weeks, enzyme concentrations decreased than controls. Glutathione (GSH) concentration was reduced after exposure compared to controls. As to $S$. mansoni infected snails, activity of CAT decreased by exposure to extract compared to untreated infected groups. SOD \& GSH activities were increased after $24 \mathrm{~h}$ and one week of treating infected snails with tested concentrations compared infected controls, after 4 weeks of exposure to $\mathrm{LC}_{25} \mathrm{GSH}$ concentrations did not significantly different from infected untreated controls.

Table 1: Molluscicidial activity of water and methanol extracts of $C$. citrinus against B. alexandrina (24 hrs exposure):

\begin{tabular}{|c|c|c|c|c|c|}
\hline Extract & $\mathrm{LC}_{10} \mathrm{ppm}$ & $\mathrm{LC}_{25} \mathrm{ppm}$ & $\mathrm{LC}_{50} \mathrm{ppm}$ & $\mathrm{LC}_{90} \mathrm{ppm}$ & Slope \\
\hline methanol & 9.3 & 17.2 & 22.3 & 37.8 & 1.6 \\
\hline water & 114.1 & 140.0 & 168.9 & 223.6 & 1.3 \\
\hline
\end{tabular}


Table 2: Effect of methanol extract of C. citrinus leaves on survival rate at $1^{\text {st }}$ shedding, infection rate, prepatent period, duration of shedding and cercarial production of B. alexandrina exposed to S. mansoni miracidia (reduction\%):

\begin{tabular}{|l|l|l|l|l|l|l|}
\hline $\begin{array}{l}\text { Miracidial } \\
\text { exposure }\end{array}$ & Conc. & Survival\% & $\begin{array}{l}\text { Infec- } \\
\text { tion\% }\end{array}$ & $\begin{array}{l}\text { Prepatent } \\
\text { period }\end{array}$ & $\begin{array}{l}\text { duration of } \\
\text { shedding }\end{array}$ & \multicolumn{1}{c|}{$\begin{array}{c}\text { No. of cercariae } \\
\text { / snail }\end{array}$} \\
\hline $\begin{array}{l}1 \text { day pre- } \\
\text { exposure }\end{array}$ & Control & 80.00 & 81.25 & $23.15 \pm 3.36$ & $39.31 \pm 14.16$ & $4402.54 \pm 496.44$ \\
\cline { 2 - 7 } & $\mathrm{LC}_{10}$ & $65.00(18.7 \%)^{*}$ & 76.92 & $24.50 \pm 3.69$ & $31.50 \pm 7.56$ & $3951.00 \pm 891.13(10.2 \%)$ \\
\cline { 2 - 7 } & $\mathrm{LC}_{25}$ & $65.00(18.7 \%)^{*}$ & $92.31 * *$ & $27.42 \pm 4.68 * *$ & $29.17 \pm 13.95 *$ & $3590.67 \pm 590.72(18.4 \%) * * * *$ \\
\hline \multirow{2}{*}{$\begin{array}{l}15 \\
\text { post days } \\
\text { posure }\end{array}$} & $\mathrm{Control}$ & 75.00 & 86.67 & $22.08 \pm 2.63$ & $47.92 \pm 14.81$ & $3549.77 \pm 841.87$ \\
\cline { 2 - 7 } & $\mathrm{LC}_{10}$ & $55.00(26.7 \%)^{*}$ & $72.73 *$ & $23.63 \pm 3.62$ & $38.50 \pm 9.90 *$ & $2169.67 \pm 1067.04(38.9 \%) * *$ \\
\cline { 2 - 7 } & $\mathrm{LC}_{25}$ & $45.00(40.0 \%) * *$ & 88.89 & $22.75 \pm 3.24$ & $36.75 \pm 10.42 *$ & $1923.00 \pm 237.03(45.8 \%) * * *$ \\
\hline \multirow{2}{*}{$\begin{array}{l}\text { During ex- } \\
\text { posure }\end{array}$} & $\mathrm{Control}$ & 85.00 & 82.35 & $22.50 \pm 4.05$ & $36.00 \pm 15.25$ & $2907.0 \pm 735.44$ \\
\cline { 2 - 7 } & $\mathrm{LC}_{10}$ & $30.00(64.7 \%) * * *$ & $33.33 * * *$ & $21.00 \pm 0$ & $31.50 \pm 14.85$ & $2896.5 \pm 965.50(0.38 \%)$ \\
\cline { 2 - 7 } & $\mathrm{LC}_{25}$ & $25.00(70.6 \%)^{* * *}$ & $40.00 * * *$ & $24.50 \pm 4.95$ & $24.50 \pm 14.85$ & $1072.5 \pm 950.50(63.1 \%) * *$ \\
\hline
\end{tabular}

Table 3: Survival rate $\left(\mathrm{L}_{\mathrm{X}}\right)$ and fecundity $\left(\mathrm{M}_{\mathrm{X}}\right)$ of $S$. mansoni uninfected and infected B. alexandrina treated with sublethal concentrations of methanol extract of

\begin{tabular}{|c|c|c|c|c|c|c|c|c|c|c|c|c|c|c|c|c|c|c|}
\hline \multirow{4}{*}{$\begin{array}{c}\text { Exposure } \\
\text { period } \\
\text { (weeks) }\end{array}$} & \multicolumn{6}{|c|}{ Control (untreated) } & \multicolumn{12}{|c|}{ Treated } \\
\hline & \multirow{2}{*}{\multicolumn{3}{|c|}{ Uninfected }} & \multirow{2}{*}{\multicolumn{3}{|c|}{ Infected }} & \multicolumn{6}{|c|}{ Uninfected } & \multicolumn{6}{|c|}{ Infected } \\
\hline & & & & & & & \multicolumn{3}{|c|}{$\mathrm{LC}_{10}(9.3 \mathrm{ppm})$} & \multicolumn{3}{|c|}{$\mathrm{LC}_{25}(17.2 \mathrm{ppm})$} & \multicolumn{3}{|c|}{$\mathrm{LC}_{10}(9.3 \mathrm{ppm})$} & \multicolumn{3}{|c|}{$\mathrm{LC}_{25}(17.2 \mathrm{ppm})$} \\
\hline & $\mathrm{Lx}$ & $\mathrm{Mx}$ & LxMx & $\mathrm{Lx}$ & $\mathrm{Mx}$ & LxMx & $\mathrm{Lx}$ & Mx & LxMx & $\mathrm{Lx}$ & $\mathrm{Mx}$ & LxMx & $\mathrm{Lx}$ & $\mathrm{Mx}$ & LxMx & $\mathrm{Lx}$ & $\mathrm{Mx}$ & $\mathrm{LxMx}$ \\
\hline 0 & 1.00 & 5.30 & 5.30 & 1.00 & 5.30 & 5.30 & 1.00 & 5.30 & 5.30 & 1.00 & 5.30 & 5.30 & 1 & 5.30 & \begin{tabular}{l|l}
5.30 \\
\end{tabular} & 1 & 5.30 & 5.30 \\
\hline 1 & 1.00 & 3.70 & 3.70 & 0.76 & 1.6 & 1.22 & 0.95 & 1.40 & 1.33 & 0.73 & 3.10 & 2.26 & 0.7 & 1.4 & 0.98 & 0.65 & 1.1 & 0.72 \\
\hline 2 & 1.00 & 4.50 & 4.50 & 0.6 & 0.2 & 0.12 & 0.85 & 2.00 & 1.70 & 0.70 & 2.40 & 1.68 & 0.43 & 0.04 & 0.018 & 0.38 & 0.8 & 0.3 \\
\hline 3 & 0.90 & 2.70 & 2.43 & 0.56 & 1.1 & 0.62 & 0.73 & 0.01 & 0.01 & 0.65 & 1.10 & 0.72 & 0.23 & 0.02 & 0.005 & 0.06 & 0.1 & 0.006 \\
\hline 4 & 0.90 & 6.50 & 5.85 & 0.23 & 0.8 & 0.184 & 0.56 & 0.00 & 0.00 & 0.50 & 0.01 & 0.01 & 0.07 & 0.0 & 0.0 & 0.0 & 0.0 & 0.0 \\
\hline $\begin{array}{c}\mathrm{R} 0\left(\sum \mathrm{Lx}\right. \\
\mathrm{Mx})\end{array}$ & & & $\begin{array}{l}21 . \\
78\end{array}$ & & & $\begin{array}{c}7.4 \\
4 \\
* *\end{array}$ & & & $\begin{array}{c}8.34 \\
* *\end{array}$ & & & $\begin{array}{l}9.97 \\
*\end{array}$ & & & $\begin{array}{c}6.30 \\
* *\end{array}$ & & & \begin{tabular}{l|}
6.33 \\
$* *$
\end{tabular} \\
\hline $\begin{array}{c}\text { Reduction } \\
\mathrm{R}_{0} \%\end{array}$ & & & & & & 65.8 & & & 61.7 & & & 54.2 & & & 71.1 & & & 70.9 \\
\hline
\end{tabular}

Table 4: Total number \& types (\%) of hemocytes in S. mansoni uninfected and infected B. alexandrina treated with methanol extract of C. citrinus: Hyalinocytes (Hy), Small granulocytes (SG) and Large granulocytes (LG).

\begin{tabular}{|c|c|c|c|c|c|c|c|}
\hline \multirow{3}{*}{$\begin{array}{l}\text { Expos- } \\
\text { ure } \\
\text { period }\end{array}$} & \multirow{3}{*}{$\begin{array}{l}\text { Hemocytes (No.) } \\
\text { \& Types (\%) }\end{array}$} & \multicolumn{2}{|c|}{ Control } & \multicolumn{4}{|c|}{ Treated } \\
\hline & & \multirow{2}{*}{ Uninfected } & \multirow{2}{*}{ Infected } & \multicolumn{2}{|c|}{ Uninfected } & \multicolumn{2}{|c|}{ Infected } \\
\hline & & & & $\mathrm{LC}_{10}$ & $\mathrm{LC}_{25}$ & $\mathrm{LC}_{10}$ & $\mathrm{LC}_{25}$ \\
\hline \multirow{4}{*}{$24 \mathrm{~h}$} & Total no. & $2340 \pm 295$ & $1600 \pm 155$ & $3170 \pm 320^{*}$ & $3250 \pm 370 *$ & $2050 \pm 250 *$ & $\begin{array}{c}3000 \pm 265^{* *} \\
*\end{array}$ \\
\hline & $\mathrm{Hy}$ & 21 & 8 & 25 & $31 *$ & 12 & 8 \\
\hline & SG & 26 & 38 & 29 & 35 & 42 & $20 * *$ \\
\hline & LG & 53 & 54 & 46 & $34 *$ & 46 & $72 * *$ \\
\hline \multirow{4}{*}{ 1week } & Total no. & $2150 \pm 306$ & $1150 \pm 128$ & $720 \pm 140 * * *$ & $850 \pm 90 * * *$ & $250 \pm 48 * * *$ & $750 \pm 52 * * *$ \\
\hline & $\mathrm{Hy}$ & 18 & 54 & 21 & $30 *$ & $33 * *$ & 48 \\
\hline & SG & 32 & 28 & $56 * * *$ & $55 * * *$ & $54 * * *$ & 33 \\
\hline & LG & 50 & 18 & $23 * * *$ & $15 * * *$ & 13 & 19 \\
\hline \multirow{4}{*}{ 2week } & Total no. & $2500 \pm 290$ & $3500 \pm 344$ & $2350 \pm 203$ & $3100 \pm 380$ & $2900 \pm 380$ & $2450 \pm 205^{* *}$ \\
\hline & $\mathrm{Hy}$ & 17 & 51 & $46 * * *$ & $49 * * *$ & 50 & 44 \\
\hline & SG & 33 & 21 & 33 & 22 & 29 & $37 * *$ \\
\hline & LG & 50 & 28 & $21 * * *$ & $29 * *$ & 21 & 19 \\
\hline \multirow{4}{*}{ 4week } & Total no. & $2700 \pm 307$ & $2950 \pm 325$ & $2600 \pm 230$ & $3050 \pm 270$ & $2250 \pm 223^{*}$ & $1950 \pm 134 * *$ \\
\hline & $\mathrm{Hy}$ & 19 & 34 & 13 & 18 & 28 & 28 \\
\hline & SG & 40 & 45 & $22 * *$ & 29 & 37 & $21 * * *$ \\
\hline & LG & 41 & 21 & $65 * * *$ & $53 *$ & $35 * * *$ & $51 * * *$ \\
\hline
\end{tabular}


Table 5: Antioxidants in tissue homogenate of $S$. mansoni uninfected and infected B. alexandrina exposed to methanol extract of $C$. citrinus for $24 \mathrm{~h}$ weekly for 4 successive weeks:

\begin{tabular}{|c|c|c|c|c|c|c|c|}
\hline \multirow{3}{*}{$\begin{array}{l}\text { Exposure } \\
\text { period }\end{array}$} & \multirow{3}{*}{ Enzymes } & \multicolumn{2}{|c|}{ Control } & \multicolumn{4}{|c|}{ Treated } \\
\hline & & \multirow{2}{*}{ Uninfected } & \multirow{2}{*}{ Infected } & \multicolumn{2}{|c|}{ Uninfected } & \multicolumn{2}{|c|}{ Infected } \\
\hline & & & & $\mathrm{LC}_{10}$ & $\mathrm{LC}_{25}$ & $\mathrm{LC}_{10}$ & $\mathrm{LC}_{25}$ \\
\hline \multirow{3}{*}{$24 \mathrm{~h}$} & SOD & $257.3 \pm 14.3$ & $345.4 \pm 13.2$ & $274.4 \pm 8.7$ & $290.7 \pm 9.4 *$ & $407.8 \pm 18.2^{* *}$ & $512.5 \pm 15.6$ **** \\
\hline & GSH & $4.1 \pm 0.4$ & $2.6 \pm 0.7$ & $3.6 \pm 0.25$ & $2.9 \pm 0.3 * *$ & $3.3 \pm 0.85$ & $2.6 \pm 0.76$ \\
\hline & LPO & $103.3 \pm 3.2$ & $123.7 \pm 5.6$ & $102.0 \pm 1.9$ & $94.7 \pm 2.4^{*}$ & $109.8 \pm 7.5^{*}$ & $117.4 \pm 6.0$ \\
\hline \multirow{2}{*}{ 1week } & GSH & $3.7 \pm 0.27$ & $4.2 \pm 0.6$ & $2.7 \pm 0.31 * *$ & $2.3 \pm 0.28 * *$ & $5.2 \pm 0.6^{*}$ & $5.8 \pm 0.55^{*}$ \\
\hline & LPO & $107.8 \pm 2.6$ & $142.4 \pm 6.9$ & $112.3 \pm 3.4$ & $119.4 \pm 2.8^{* *}$ & $106.5 \pm 4.1 * * *$ & $117.7 \pm 3.9 * *$ \\
\hline \multirow{3}{*}{2 week } & SOD & $248.5 \pm 9.8$ & $322.9 \pm 9.8$ & $200.7 \pm 7.4 * *$ & $217.6 \pm 9.6^{*}$ & $199.4 \pm 10.6^{* * * *}$ & $204.7 \pm 13.2 * * *$ \\
\hline & CAT & $24.7 \pm 2.2$ & $27.4 \pm 8.7$ & $14.7 \pm 5.4 *$ & $12.6 \pm 3.9 * *$ & $21.6 \pm 2.7$ & $14.5 \pm 3.8^{*}$ \\
\hline & GSH & $4.2 \pm 0.25$ & $6.4 \pm 0.73$ & $3.0 \pm 0.27 * *$ & $2.5 \pm 0.18 * * *$ & $5.9 \pm 0.75$ & $7.5 \pm 0.63$ \\
\hline 4 week & LPO & $106.2 \pm 2.2$ & $99.4 \pm 5.8$ & $96.5 \pm 4.7 *$ & $81.7 \pm 7.8 * *$ & $134.8 \pm 6.9 * *$ & $151.6 \pm 11.7 * *$ \\
\hline
\end{tabular}

Discussion

Although chemotherapy is one of the most important methods for schistosomiasis control, there is still a need for more selective and efficient molluscicides for controlling the snail intermediate hosts of this parasite (WHO, 2010). The current data showed high toxicity of the plant methanol extract to the snails in comparison with water extract. This was supported by the pronounced negative impact of low con-centrations from this extract on survival rates of $S$. mansoni infected and uninfected snails compared to uninfected untreated (clean control) snails recorded in this work. This agrees with Kamel et al. (2010) on the high molluscicidal activity of methanol extract from the plant Draceana draco in comparison with the water suspension of its dry powder against $B$. alexandrina snails.

The present results showed a marked reduction in survival rates of $S$. mansoni uninfected B. alexandrina exposed for $24 \mathrm{~h} / \mathrm{week}$ for 4 successive weeks to sublethal concentrations from methanol extract of the plant C. citrinus in comparison with uninfected untreated control snails. This wass in agreement with previous records on survival rate of $B$. alexandrina snails post exposure to plants Syzygium jambos (Gawish, 2008) and H. canariensis (Abdel Rahman and Hassan, 2008). Similar observations were recorded post exposure of $B$. alexandrina snails to the plants D. stramonium and S. sesban (Mahmoud et al., 2011) and Z. officinale (Bakry et al, 2013). The toxic effect of C. citrinus to the snails may be due to the presence of the active ingredients cyanidine, delphinine, flavonoids, ursolic acid and saponins (Watson and Dallwitz, 1992). Molluscicidal activities of the plants Cestrum purpureum and Yucca filamentose marginata (Hamid et al, 2015 a; b) against $B$. alexandrina snails were due to the presence of the active chemical groups saponins, sterols and flavonoids. Undoubtedly, there was a high correlation between plants containing saponins and their molluscicidal activity (Lemma, 1970). The survival rate $\left(\mathrm{L}_{\mathrm{X}}\right)$ of snails exposed to $S$. mansoni miracidia (infected untreated snails) was less than that of normal treated control snails, which indicated that infection was considerably harmful to snails. This coincided with Abdel Hamid et al. (2007) and ElEmam et al. (2015) on the low survival rate of B. alexandrina post infection with $S$. $m a$ nsoni and/or E. liei.

The results revealed a suppression of $S$. mansoni cercarial production from $B$. alexandrina exposed to low concentrations of $C$. citrinus methanol extract for $24 \mathrm{~h}$ either pre-, during or post-miracidial exposure, in addition to a decrease in snails' survival rates and in duration of cercarial shedding.

This was supported by the disturbances in the activities of the oxidative enzymes and 
total number and types of hemocytes of snails infected and treated with this extract that could be a reflection of the interruption in their physiological and defence mechanisms which rendering them to be unsuitable for development of $S$. mansoni larval stages within their tissues. These findings agreed with using different plant species against infectivity of $S$. mansoni miracidia to $B$. alexandrina and on cercarial production from infected ones (Sharaf El-Din et al, 2001; Mahmoud et al, 2011).

The results elicited few snails' eggs were laid by $B$. alexandrina snails post exposure to methanol extract which reflected on suppression of their net reproductive rate $\left(\mathrm{R}_{0}\right)$ compared to control group. Also, treated snails stopped oviposition at the $4^{\text {th }}$ week of the experiment. This agreed with Hasheesh et al. (2011) on egg lying of B. truncatus exposed to methanol extract of the plant $S$. sesban. Similar observations were recorded on suppressing egg laying of $B$. alexandrina post continuous exposure to ethanol extract of the plant Z. officinale (Bakry et al, 2013). This was supported by the present adverse effects of the tested extract on the histological structure of their digestive gland and on morphological features of their hemocytes. Ibrahim (2006) found that snail's reproduction is an energy demanding process and any energy diverted by snails treated with molluscicides to detoxificate and repair the damage in their tissues exerted by these compounds could potentially reduce their fecundity and reproductive rates. Similarly, the fecundity and reproductive rates of $B$. alexandrina were highly suppressed post exposure to sublethal concentrations of fungicide Topas (Mohamed et al, 2010) and the dry powder of $D$. stramonium and $S$. sesban (Mahmoud et al, 2011). This reduction in fecundity could be due to lipophilic pattern of botanical extracts which affect the lipid layers of the cell membrane of treated snails that destroy their specific permeability properties and this may lead to water loss causing dehydration that might lead to abnormal- ities of egg-laying capacity of these snails (Rashed, 2002).

Histological examination of digestive gland of $S$. mansoni infected and uninfected $B$. alexandrina snails treated with $C$. citrinus methanol extract revealed degeneration of gland tubules in addition to atrophied shrunked sporocysts, big vacuoles and degeneration of connective tissue between the gland tubules. This was in line with El-Deeb and El-Nahas (2005) who recorded severe damage in the digestive and hermaphrodite glands of $B$. alexandrina treated with Euphorbia nubica extract. Also, Bode et al. (1996) noticed an increase in secretory cells and decreased in digestive ones besides an intense autolysis of cell membrane structure in the digestive gland of $B$. glabrata snails treated with T. tetraptera extract. Similar, chloroform extract of the plant $H$. tuberculatum (Rizk et al, 2012) and methanol extract of Callistemon viminalis leaves (Gohar et al, 2014) destruct the epithelial layer and degenerate the secretory cells of $B$. alexandrina digestive gland.

The present increment of total number of hemocytes in B. alexandrina treated with $C$. citrinus post $24 \mathrm{~h}$ of exposure to $S$. mansoni miracidia as well as in normal treated snails could be an immediate stimulation of their internal defense system to attack and encapsulate the invading miracidia and to take a part in repairing the tissue damages caused by the parasite penetration, also an attempt to decrease and minimize the harmful effects of the plant extract. These results agreed with Araque et al. (2003) observations on migration of $B$. glabrata hemocytes towards the invasive $S$. mansoni miracidia and surrounding them completely. Similar observations were found in Oncomelonia nosophora snails infected with $S$. japonicum (Sasaki et $a l, 2005)$ and in B. alexandrina infected with $S$. mansoni and treated with $M$. azadrach fruit water extract (Mohamed et al, 2006). Sharaf El-Din (2003) reported that double infection of B. alexandrina with $S$. mansoni and $E$. liei increased the hemocytes in their 
hemolymph and added that treatment could stimulate hematopoietic organs to produce a number of new undifferentiated hemocytes through the first three weeks post exposure to miracidia.

Hemolymph granulocytes and hyalinocytes of $B$. alexandrina infected with $S$. mansoni only and of those infected and treated with plant extract suffered from deleterious morphological deteriorations, due to their important role in defense mechanism against these stresses (infection and plant extract). Similar results were observed by Eissa et al. (2002) who noticed deformation and hemolysis of hemocytes with ruptured cell membranes and degenerated nuclei of $B$. alexandrina snails exposed to E. peplus water suspension. Also, B. alexandrina hemocytes showed obvious abnormalities and irregular aggregation especially in snails exposed continuously for 21 days to $\mathrm{LC}_{25}$ of Artemether (Mossalem et al, 2013). Granulocytes and hyalinocytes showed cell apoptosis with degenerated cytoplasm, released granules and shrinked nucleus in $B$. alexandrina treated with $\mathrm{LC}_{10} \& \mathrm{LC}_{25}$ of the herbicides Herphosate and Stomp (Abdel-Ghaffar et al, 2016) and silver nanoparticles of the fungi $P$. variotii and A. niger (Abdel-Hamid and Mekawy, 2014).

In the present results, the activities of the antioxidant enzymes CAT \& SOD increased in tissue homogenate of uninfected snails one week post exposure to $\mathrm{LC}_{10} \& \mathrm{LC}_{25}$. The activities after $2 \& 4$ weeks exposure were less than in control groups. This deterioration in may be due to snails immune system activation. This agreed with Hamed et al. (2006) who found that exposure of $B$. alexandrina to $A$. attenuate increased the activities of CAT and SOD. Enhancement of oxygen free radicals production post snails exposure stimulated antioxidant activities to cope with increased oxidative stress and protect snails' cells from damage (Torres et al., 2002).

The current data exhibited no changes in the activity of the antioxidant enzyme GSH in tissue homogenate of $S$. mansoni infected B. alexandrina snails treated with $\mathrm{LC}_{10}$ and $\mathrm{LC}_{25}$ of the plant $C$. citrinus methanol extract. This is in agreement with Kristoff $e t$ al. (2008) who reported that there is no change in GSH activity in B. glabrata snails exposed to some organophosphate pesticides. But, El-Emam et al. (2015) found an elevation in GSH activity in hemolymph of $B$. alexandrina snails exposed to the nematode $P$. hermaphrodita and/or S.mansoni miracidia. It was stated that the increase in GSH activity was associated by a depletion of lipid peroxide in snails exposed to S.mansoni miracidia and/or the larvae of the nematode $P$. hermaphrodita (Abou-Elnour et al, 2015). This was previously documented by Fahmy et al. (2014) who observed a correlation between enhancement of lipid perioxidation and consequence depletion of GSH in B. alexandrina snails exposed to zinc oxide nanoparticles.

\section{Conclusion}

The outcome results showed that $C$. citrinus methanol extract has a molluscicidal potency against $B$. alexandrina snails and reduce $S$. mansoni cercarial production from infected snails which could reduce schistosomiasis transmission. But, isolation of the plant active ingredients needs more studies against other snails of medical importance.

\section{References}

Abdel-Ghaffar, F, Ahmed, AK, Bakry, FA, Rabei, I, Ibrahim, A, 2016: The impact of three herbicides on biological and histological aspects of $B$. alexandrina, intermediate fost of $S$. mansoni. Malacol. 59, 2:197-210.

Abdel-Hamid, H, Mekawey, AI, 2014: Biological and hematological response of Biomphalaria alexandrina to mycobiosynthesis silver nanoparticles. J. Egypt. Soc. Parasitol. 44, 3:626-36. Abdel-Hamid, H, El-Husieny, A, Tantawy, A, El-Dafrawy, SM, 2007: Histological studies on the consequence antagonism of Echinostoma liei to Schistosoma mansoni in Biomphalaria alexandrina snails. Egypt. J. Exp. Biol. (Zool) 3:14550.

Abdel Rahman, EH, Hassan, SE, 2008: Molluscicidal saponins from leaves of Hedera canariensis. J. Egypt. Soc. Parasitol. 38, 1:293-304. 
Abou-Elnour, BM, El-Emam, MA, Mahmoud, MB, Ibrahim, WL, Youssef, AA, 2015: Alternations in parasitological, biochemical and molecular parameters of Biomphalaria alexandrinasnails, intermediate host of Schistosoma mansoni, induced post exposure to the proposed snail biocontrol agent Phasmarhabditis hermaphrodita nematode. Asian Pacific J. Trop. Dis. 5, 12:957-63.

Aebi, H, 1984: Catalase in vitro. Meth. Enzymol. 105:121-6.

Araque, W, Barrios, EE, Rodriguez, P, Delgado, VS, Finol, HJ, 2003: Ultrastructural study of the in vitro interaction between Biomphalaria glabrata I hemocytes and Schistosoma mansoni miracidia. Mem. Inst. Oswaldo. Cruz 98, 7I:90513.

Arumugam, M, Romestand, B, Torreilles, J, Roch, P, 2000: In vitro production of superoxide and nitric oxide (as nitrite and nitrarte) by Mytilus galloprovincia haemocytes upon incubation with PMA or laminarin or during yeast phagocytosis. Eur. J. Cell Biol. 79:513-9.

Bakry, FA, Abd El-Atti, MS, Ismail, S, 2013:

Effect of Zingiber officinal (ginger) on electrophoresis analysis and biochemical aspects of Biomphalaria alexandrina snails infected with Schistosoma mansoni. Int. J. Sci. Engin. Res. 4, 11:1147-54.

Bakry, FA, 2009: Use of some plant extracts to control Biomphalaria alexandrina snails with emphasis on some biological effects. Pest. Biochem. Physiol. 95:159-65.

Belete, EM, 2015: Schistosomiasis control strategies, with emphasis on snail control using molluscicides. J. Hlth. Sci. Res. 5, 8:572-84.

Beutler, E, Duron, O, Kelly, MB, 1963: Improved method for the determination of blood glutathione. J. Lab. Clin. Med. 61:882-8

Bode, AU, Adewunmi, CO, Dorfler, G, Becer, W, 1996: The effect of extracts from Tetrapleura tetraptera (Taub.) and Bayluscide on cells and tissue structures of Biomphalaria glabrata (Say). J. Ethnopharmacol. 50, 2:103-13.

Dhawan, V, 2005: Garlic supplementation prevents oxidative DNA damage in essential hypertension, Mol. Cell. Biochem. 275:85-94.

Eissa, SH, Rizk, ET, Abou-Shafey, AE, Atlam, A, 2002: Toxicological effects of Euphorbia peplus water suspension on haemocytes of the freshwater snails Biomphalaria alexandrina and Lanistes carinatus. Proc. ICBS, 2, 2:417-47.
Dongmo, BN, Dongmo, PM, Ngoune, LT, Kwazou, NL, Zollo, PH, et al, 2010: Antifungal activities of essential oils of some Cameroonian Myrtaceae on Aspergillus flavus Link ex. Fries. Asian J. Exp. Biol. Sci. 1:907-14.

El Dib, RA, El-Shenawy, SM, 2008: Phenolic constituents and biological activities of the aerial parts of Callistemon viminalis (Sol. Ex Gaertner) G.Don ex Loudon. Bull. Fac. Pharma. (Cairo Univ.) 46:223-35.

El-Deeb, FA, El-Nahas, HA, 2005: Comparative studies on the impact of three Egyptian plants against Biomphalaria alexandrina and Lymnaea caillaudi snails. J. Egypt. Ger. Soc. Zool. 46, D:103-24.

El-Emam, MA, Mahmoud, MB, Abou-El Nour, BM, Ibrahim, WL, Youssef, AA, 2015: Impact of double infection of Biomphalaria alexandrina snails with schistosoma mansoni and Echinostoma liei on their biological, molecular, immunological and histological parameters. J. Biol. Chem. Environ. Sci. 10, 1: 131-45.

Fahmy, SR, Abdel-Ghaffar, F, Bakry, FA, Sayed, DA, 2014: Ecotoxicological effect of sublethal exposure to zinc oxide nanoparticles on freshwater snail Biomphalaria alexandrina. Arch. Environ. Contam. Toxicol. 67:192-202.

Gawish, F, Mossalem, HS, Abu El Einin, H, 2008: Bioassay of the plant Callistemon Citrinus against Bulinus truncatus snails and their infection with Schistosoma haematobium. Egypt. J. Schisto. Infect. Endem. Dis. 30:1-63.

Gawish, FA, 2008: Activity of the plant Syzygium jambos against Biomphalaria alexandrina snails' reproduction and infection with Schistosoma mansoni, New Egypt. J. Med. 39: 103-10.

Gohar, AA, Maatooq, GT, Gadara, SR, Aboelmaaty, WA, El-Shazly, AM, 2014: Molluscicidal activity of the methanol extracts of Callistemon viminalis (Sol. ex Gaertner) G.Don ex Loudon Fruits, Bark and Leaves against Biomphalaria alexandrina snails. Iran. J. Pharm. Res. 13, 2:505-14

Hamid, M, El-Amin, S, Abdel-Fattah, 2015a: Isolation and identification of some compounds from molluscicidaly active plant Yucca filamintaza "Marginata". Archives 1:19-30.

Hamid, M, El-Amin, S, Abdel-Fattah, 2015b: Molluscicidal activity of some constituents isolated from Cestrum purpureum. Archives 2:5972.

Hamed, RR, Maharem, TM, Farid, NM, Ramadan, Kh, Abdel Aziz, MH, 2006: Effect of 
Agave attenuata extracts on detoxification enzymes of Biomphlaria alexandrina. Environment 26:157-64.

Hasheesh, WS, Mohamed, RT, Abd El-Monem, S, 2011: Biological and physiological parameters of Bulinus truncatus snails exposed to methanol extract of the plant Sesbania sesban plant. Adv. Biol. Chem. 1:65-73.

Ibrahim, MM, 2006: Energy allocation patterns in Biomphalaria alexandrina snails in response to cadmium exposure and Schistosoma mansoni infection. Exp. Parasitol. 112:31-6.

Kamel, EG, El-Emam, MA, Mahmoud, SSM, Fouda, FM, Bayaumy, FE, 2010: Attenuation of Schistosoma mansoni cercarial infectivity to albino mice by methanol extract of some plant species. Pest. Bioc. Phys. 98:342-8.

Kamel, EG, El-Emam, MA, Mahmoud, SSM, Fouda, FM, Bayaumy, FE, 2011: Parasitological and biochemical parameters in Schistosoma mansoni infected mice with methanol extract of the plants Chenopodium ambrosioides, Conyza dioscorides and Sesbania sesban. J. Parasitol. 60:388-92.

King, CH, Bertsch, D, 2015: Historical perspective: Snail control to prevent schistosomiasis. J. PLoS. Negl. Trop. Dis. 9, 4:36-57

Kristoff, G, Verrengia Guerrero, NR, Cochon, AC, 2008: Effects of azinphos-methyl exposure on enzymatic and non-enzymatic antioxidant defenses in Biomphalaria glabrata and $\mathrm{Lu}$ mbriculus variegatus. Chemosphere 72:1333-9.

Larson, MK, Bender, RC, Bayne, CJ, 2014: Resistance of Biomphalaria glabrata 13-16-R1 snails to Schistosoma mansoni PR1 is a function of haemocyte abundance and constitutive levels of specific transcripts in haemocytes. Int. J. Parasitol. 44:343-53

Lemma, A, 1970: Laboratory and field evaluation of the molluscicidal properties of Phytolacca dodecandra. Bull. WHO, 42 597-612.

Livingstone, DR, Chipman, JK, Lowe, DM, Minier, C, Mitchelmore, CL, et al, 2000: Development of biomarkers to detect the effects of organic pollution on aquatic in vertebrates: recent molecular, genotoxic, cellular and immunological studies on the comm; On mussel (Mytilus edulis L.) and other mytilids. Int. J. Environ. Pollut. 13:56-91.

Mahmoud, MB, Ibrahim, WL, AbouEl-Nour, BM, EL-Emam, MA, Youssif, AA, 2011: Biological and biochemical parameters of Biomphalaria alexandrina snails exposed to the plants
Datura stramonium and Sesbania sesban as water suspensions of their dry powder. Pest. Bioch. Physiol. 99: 96-104.

Mohamed, AH, Osman, GY, Mohamed, AM, Elhoseiny, A, 2006: Efficiency of Melia azadrach fruit water extract on Biomphalaria alexandrina snails. Egypt. J. Exp. Biol. (Zool.), 2:181-8. Mohamed, AH, Osman, GY, Mohamed, AM, Elhoseiny, A, 2010: Effect of Topas (fungicide) on egg laying capacity and hermaphrodite gland of Biomphalaria alexandrina snails. Egypt. J. Exp. Biol. (Zool.), 6, 1:99-105.

Mohamed, AM,El Emam, MA, Osman, GY, Abdel-Hamid, H, Ali, REM, 2012: Effect of basudin, selecron and the phytoalkaloid colchicine (pesticides) on biological and mole-cular parameters of Biomphalaria alexandrina snails. Pest. Biochem. Physiol. 102: 68-78.

Mossalem, HS, Abdel-Hamid, H, El- Shinnawy, NA, 2013: Impact of Artemether on some histological and histochemical parameters in Biomphalaria alexandrina. Afr. J. Pharm. Pharmacol. 7, 31:2220-30.

Nduku, WK, Harrison, AD, 1980: Cationic responses of organs and haemolymph of Biomphalaria pfeifferi (Krauss), Biomphalaria glabrata (Say) and Helisoma trivolvis (Say) (Gastropoda: Planorbirdae) to cationic alterations of the medium. Hydrobiologia 68:119-38

Ohkawa, H, Ohishi, N, Yagi, K, 1979: Assay for lipid peroxides in animal tissues by thiobarbituric acid reaction. Ana.1 Biochem. 95:351-8.

Ragheb, M, El-Tayeb, T, El-Emam, M, Amer, M, Bashter, A, 2013: Copper chlorophyllin and magnesium chlorophyllin as molluscicidal agents against Biomphalaria alexandrina snails. Asian Acad. Res. J. Multidisc. 1, 16:229-54.

Rashed, AA, 2002: Biological studies on the snail intermediate hosts of schistosomiasis with a special emphasis on using larval Echinostomes as biocontrol agents against larval schistosomes and snails. J. Egypt. Soc. Parasitol. 32: 775-84.

Renwrantz, L, Schmalmack, W, Redel, R, Friebel, B, Schneewei, H, 1996: Conversion of phenoloxidase and peroxidase indicators in individual haemocytes of Mytilus edilis specimens and isolation of phenoloxidase from haemocyte extract. J. Comp. Physiol. B, 165:647-58.

Rizk, MZ, Metwally, NS, Hamed, MA, Mohamed AM, 2012: Correlation between steroid sex hormones, egg laying capacity and cercarial shedding in Biomphalaria alexandrina snails 
after treatment with Haplophyllum tuberculatum. Exp. Parasitol. 132: 171-9.

Sampath, S, Kalimuthu, B, Veeramani, V, Janardhanam, S, Baran, MA, et al, 2016: Evaluation of total antioxidant and free radical scavenging 3 activities of Callistemon citrinus (Curtis) Skeels extracts 4 by biochemical and electron paramagnetic resonance analyses. $\underline{\mathrm{RSC}}$ Adv. 6:12382-90.

Sasaki, Y, Kirinoki, M, Chigusa, Y, 2005: Comparative studies of the defense mechanism against Schistosoma japonicum of schistosomesusceptible and -resistant Oncomelania nosophora. Parasitol. Int. 54, 3:157-65.

Sharaf EI-Din, AT, 2003: Effects of double infection with Echinostoma liei and Schistosoma mansoni on hemoglobin content and circulating haemocytes in the haemolymph of the host snail Biomphalaria alexandrina. Egypt. J. Schist. Infect. Endem. Dis. 25:41-52.

Sharaf El-Din, AT, Bakry, FA, Tantawy, A, 2001: Molluscicidal activity of Zygophyllum simplex (Family; Zygophyllaceae) against $B i$ omphalaria alexandrina and Bulinus truncatus. Egypt. J. Aqua. Biol. Fish. 4:131-43.

\section{Explanation of figures}

Fig. 1: Light photomicrographs showing transverse section in digestive gland of B. alexandrina. (A) untreated controls, (B) exposed for 24h to $\mathrm{LC}_{50}$ of extract of $C$. citrinus, $(\mathrm{C})$ exposed to $\mathrm{S}$. mansoni miracidia only showed cercariae and sporocycts in digestive gland after cercarial shedding, (D) exposed for $24 \mathrm{~h}$ to $\mathrm{S}$. mansoni and treated with $\mathrm{LC}_{50}$ stained with $\mathrm{H}$ and $\mathrm{E}$. (At) atrophied cells, (Cer) cercariae, (Ct) connective tissues, (E) epithelial cell, (H) hyaline substance, (L) lumen, shrunk sporocycts (S), (Sp) sporocyst, (V) vacuoles.

Fig. 2: Light photomicrograph of hemocytes from B. alexandrina snail. (A) control, (B\&C) morphological abnormalities in hemocytes post 24 h of exposure to $C$. citrius extract, (D) S. mansoni infected B. alexandrina, (E) infected treated with extract of $C$. citrius stained with Giemsa stain (1000x). (CGR) condensed granules, (Cy) cytoplasm, (Dw), deformed cell wall, (Fp) filopodia, (GR) granules, (Hy) haylinocytes, (LG, large and SG, small) granulocytes, (N) nucleus, (Ir) irregular cell wall.
Southwood, TRE, 1978: Ecological Methods. Halsted Press, Chapman and Hall. London.

Spiegel, D, 1981: Viet man grief work using hypnosis. Am. J. Clin. Hyp. 24, 1:33-40.

Tantawy, A, Mostafa, BB, Sharaf El-Din, AT, 2004: agcicidal activity of Synadenium gra-nd cates the intermediate host snails of schistosomiasis in Egypt and their infectivity with the parasite. Egypt. J. Sci. 4:183-96. mangroves on Santa Catarina Island, Brazil. Mari. Poll. Bull. 44:923-32.

Watson, L, Dallwitz, MJ, 1992: The families of flowering plants: descriptions, illustrations, identification, and information retrieval. Website http://biodiversity.uno.edu/ delta/

, 2010: Schistosomiasis, Fact Sheet No. /factsheets/fs115/en.

WHO, 2016: Schistosomiasis, Fact Sheet No. 115, updated February http: // www.WHO.int/ mediacentre/ factsheets/fs115/en. 


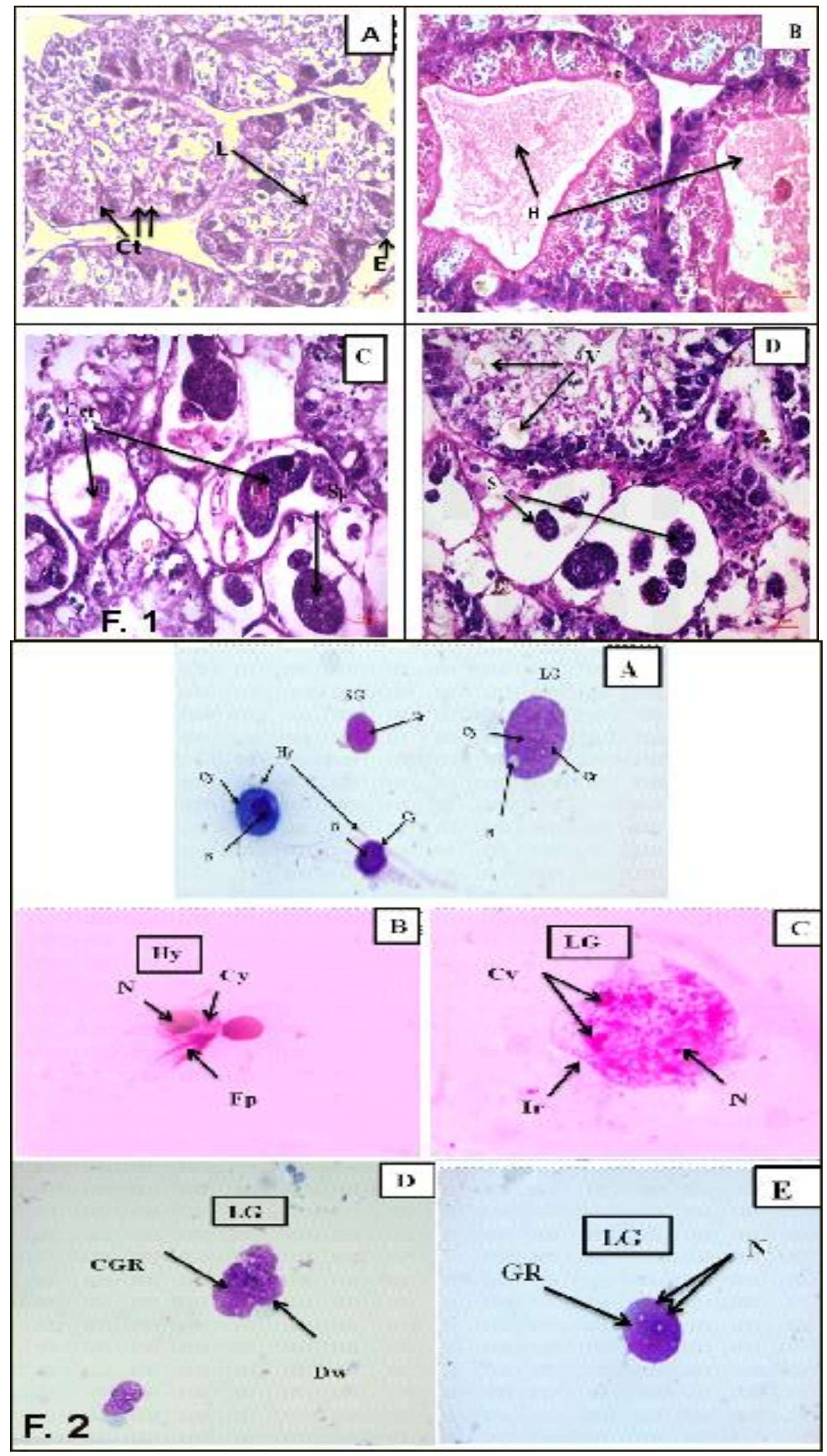

